Jurnal Kesehatan Masyarakat
http://journal.unnes.ac.id/nju/index.php/kemas

\title{
Health-Related Quality of Life among the Elderly Living in the Community and Nursing Home
}

\author{
Susiana Nugraha ${ }^{\bowtie}$, Yuna Trisuci Aprillia \\ ${ }^{1}$ Public Health Study Program, Faculty of Health Sciences, University of Respati Indonesia \\ ${ }^{2}$ Midwifery Study Program, Faculty of Health Sciences, University of Respati Indonesia
}

\begin{tabular}{l} 
Article Info \\
\hline Article History: \\
Submitted September 2019 \\
Accepted January 2020 \\
Published March 2020 \\
\hline Keywords: \\
Elderly, Quality of Life, \\
Nursing home, Community \\
\hline DOI \\
https://doi.org/10.15294/ \\
kemas.v15i3.21282
\end{tabular}

\begin{abstract}
The increasing number of the elderly population presents special challenges in the health sector with the emergence of degenerative problems and non-communicable diseases (NCD's) that may decrease the quality of life (QoL). Development in the quality of life of the elderly is an important issue for national security and development. This study using cross-sectional approach, intended to identify the differences in the quality of life among the elderly who live in the nursing homes and the community. The results showed that statistically significant differences were found in variable ages $(\mathrm{p}<001)$, education background $(\mathrm{p}<0.001)$, dependency level $(\mathrm{p}=0.024)$ for Activity Daily Living and $(\mathrm{p}<0.001)$ for Instrumental Activity Daily Living) and the overall score of QoL ( $\mathrm{p}=0.036)$. Based on this finding, the differences approach must be given in meeting the mobility needs and daily activities of the elderly who live in communities and nursing homes.
\end{abstract}

\section{Introduction}

Advancement in science and technology, as well as socioeconomic improvement, have an impact on increasing the degree of public health and life expectancy, so the number of elderly populations also increases. Until now, the population in 11 member countries of the World Health Organization (WHO) in the Southeast Asian region over the age of 60 years has amounted to 142 million and is expected to continue to triple by 2050 (UNDESA (United Nation for Departement of Economic and Social Affair), 2019).

In 2000 the number of elderlies was around 5,300,000 (7.4\%) of the total population, while in 2010 the number of elderly reached $24,000,000(9.77 \%)$ of the total population, and by 2020 it was estimated that the number of elderly reached $28,800,000(11,34 \%)$ of the total population (BPS, 2017) The increasing number of elderly is a challenge in the health sector with a tendency to develop degenerative problems and non-communicable diseases (NCD's) such as diabetes, hypertension, and mental health disorders, namely depression, dementia, anxiety disorders, and insomnia (Riskesdes, 2018). The disease will cause problems if it is not addressed or prevented because this will be a chronic and multi-pathological disease that will affect the quality of life of the elderly.

The World Health Organization defines the quality of life as an individual's perception of his life in society in the context of existing cultural and value systems related to goals, expectations, standards, and concerns (WHO, 2012). Quality of life is a very broad concept that is affected by an individual's physical, psychological, level of independence, and the relationship of the individual to the environment (Alexandre, Cordeiro, \& Ramos, 2009). The living environment is an important factor that 
affects the quality of life of the elderly (Zubritsky et al., 2013).

The elderly who live in the community generally have a relatively stable social interaction as well as a social environment compared to the elderly in nursing homes. They connected to their sources of social support such as family, friends, and relatives. On the other hand, moving to a new living environment such as an elderly home, resulting in the changes in the elderly role and requires a life adjustment not only physically but social and psychological well-being. For the elderly living in nursing home, the changing roles in the family, socioeconomic, and social community lead to setbacks in adapting to new environments and interacting with their social environments (Yuliastuti \& Anggoro, 2017). This condition may affect their psychological wellbeing furthermore to their quality of life. Unlike the elderly in the community, the elderly who live at the elderly homes will experience exposure to the environment and new friends that require the elderly to adapt positively or negatively (Yuliati, 2014).

Differences in residence cause the emergence of differences in the physical, social, economic, psychological and spiritual aspects of the elderly that can affect the health status of the elderly population who live in it (Curl, Thompson, Alves, \& Aspinall, 2016). Once a person experiences aging, he/she will experience a lot of decline in terms of physical, cognitive, and psychosocial life Borowiak \& Kostka (2004)health status, nutritional state, physical and cognitive function. Physical activity (PA also emphasizes the importance of life expectancy and quality of life for the elderly. Therefore, there is an urgent need to promote the development and protection of elderly health, especially by creating economic security, increasing employment opportunities for the elderly, and long-term care systems that cover the economic, social and health dimensions. For those reasons, developing the quality of life of Indonesian elderly is an important issue for national security and development.

This study is intended to assess the difference in quality of life-based on the construction of the quality of life such as demographic factors, health status, socioeconomic background, level of depression, level of independence/dependence in carrying out daily activities. This study measuring the QoL in 5 dimensions namely mobility, selfcare, daily activities, pain, anxiety predictors that affect the quality of life of the elderly who live in nursing homes and the elderly who live in communities.

\section{Method}

The study population was all active elderly people living in communities and in nursing homes in the West Java Region and Yogyakarta Special Region. The sample size calculation for multiple regression analysis uses the concept of power and the rule of thumb developed by Wilson Van Voorhis and Morgan, (2007). The overall model is $50+8 \mathrm{k}$, where $\mathrm{k}$ is the number of independent variables and the analysis for the individual variable model is $104+\mathrm{k}$. In this study, there are 10 independent variables so that the number of samples reached as many as 130 respondents representing each study group (institution and community). An additional $10 \%$ of cases were collected to prevent data loss. Thus, a total of $260+26$ research participants was determined, a total of 286 of the elderly participated in this study. This study conducted in Mei to September 2019, in Special Region of Yogyakarta and West Java Region, where the two regions have similarities in the elderly characteristics. This section usually consists of the description of research participants, including the number, characteristics, sampling method, and recruitment process, if necessary. This study is a descriptive analytic study using cross-sectional approach to figure out the difference in the quality of life among the elderly living in community and nursing homes.

The questionnaire became a data collection tool in this study. Questionnaire consist of a socio-demographic characteristic such as Ages, gender, educational background, and former employment status that describe the socio-economic condition. Validated standard assessment instruments used in this study include EQ-5D to assess the quality of life of the elderly, EQ-5D is a general instrument that is widely used to measure the quality of life of populations. EQ-5D is a simple instrument because it measures health status using 5 different domains. Measurements using the 
EQ-5D instrument produce the utility values needed in the Quality Adjusted Life Years (QALY) measurements in CUA pharmacologic studies. EQ-5D consists of 2 parts namely EQ5D descriptive system and EQ-5D VAS. The EQ-5D descriptive system assesses 5 health domains which include mobility, self-care, usual activity, pain/discomfort, and anxiety/ depression (Reenan \& Oppe, 2015). EQ-5D VAS assesses the health of respondents using a vertical scale with a range of $0-100$. There have been many publications on research in various countries comparing EQ-5D-3L and EQ-5D$5 \mathrm{~L}$ instruments to find out which version of the EQ-5D instrument is more suitable for use in measuring the quality of life both in healthy populations and in populations with special conditions. Validated standard assessment instruments used in this study include EQ-5D to assess the quality of life of the elderly.

Statistical analysis utilized in this study are descriptive statistics for the demographic characteristics, Mann-Whitney independent sample test employed to identify the difference in the quality of life between two groups, moreover, Pearson chi-square utilized to identify the relationship between each subdimension category of elderly quality of life.

This study pays attention to ethical considerations according to ethical standards set by the Minister of Research and Technology. Therefore, before conducting this research, researchers will first submit an ethical review at the institutional ethics committee of Respati Indonesia University. This research passed the ethical assessment with ethical clearance number: 0351/SK.KEPK/UNR/V/19, on May $10^{\text {th }}, 2019$. All study participants are signing their informed consent as their agreement in participation.

\section{Results and Discussion}

This research was conducted in 2 provinces of the Special Region of Yogyakarta and the Province of West Java. The study was conducted at the nursing home and the community. The average age of the elderly respondents in this study was 73.9 years old $( \pm$ 10.34 SD, min 60 max 99 years old) and most of them are female.

A statistical difference in ages is found

Table.1 Demographic Characteristic of Study participants

\begin{tabular}{|c|c|c|c|c|}
\hline \multicolumn{2}{|l|}{ Variables } & \multirow{2}{*}{$\begin{array}{l}\text { Nursing home } \\
(\mathrm{n}=136)\end{array}$} & \multirow{2}{*}{$\begin{array}{l}\begin{array}{l}\text { Community } \\
(\mathrm{n}=150)\end{array} \\
50(40.3 \%)\end{array}$} & \multirow{2}{*}{$\frac{\mathrm{p} \text { value }}{0.001}$} \\
\hline Ages & 75 years or more & & & \\
\hline & less than 75 years & $62(38.3 \%)$ & $100(61.7 \%)$ & \\
\hline \multirow[t]{2}{*}{ Gender } & Female & $98(48.5 \%)$ & $104(51.4 \%)$ & 0.613 \\
\hline & Male & $38(45.2 \%)$ & $46(54.8 \%)$ & \\
\hline \multirow[t]{2}{*}{ Education } & 6 years & $67(39.0 \%)$ & $105(61.0 \%)$ & 0.001 \\
\hline & more than 6 years & $68(60.2 \%)$ & $45(39.8 \%)$ & \\
\hline \multirow[t]{2}{*}{ Chronic condition } & Multi-morbidity & $37(41.6 \%)$ & $52(58.4 \%)$ & 0.173 \\
\hline & non multi-morbidity & $99(50.3 \%)$ & $98(49.7 \%)$ & \\
\hline \multirow[t]{2}{*}{ GDS } & with depressive symptom & $46(56.1 \%)$ & $36(43.9 \%)$ & 0.061 \\
\hline & without depressive symptom & $89(43.8 \%)$ & $114(56.2 \%)$ & \\
\hline \multirow[t]{2}{*}{$\mathrm{ADL}$} & Dependent & $66(55.5 \%)$ & $53(44.5 \%)$ & 0.024 \\
\hline & Independent & $70(41.9 \%)$ & $97(58.1 \%)$ & \\
\hline \multirow[t]{2}{*}{ IADL } & Dependent & $64(70.3 \%)$ & $27(29.7 \%)$ & 0.001 \\
\hline & Independent & $72(36.9 \%)$ & $123(63.1 \%)$ & \\
\hline \multirow[t]{2}{*}{ QOL } & poor QOL & $46(57.5 \%)$ & $34(42.5 \%)$ & 0.036 \\
\hline & Good QOL & $90(43.7 \%)$ & $116(56.3 \%)$ & \\
\hline \multirow[t]{2}{*}{ VAS QOL } & Poor Health & $60(53.1 \%)$ & $53(46.1 \%)$ & 0.145 \\
\hline & Good Health & $76(43.9 \%)$ & $97(52.4 \%)$ & \\
\hline
\end{tabular}


in elderly living in the nursing home and community. Elderly living in nursing home are older than those living in the community. Female elderly shows bigger number both in the nursing home and community and no significant difference between two living environments. Elderly living in nursing home are having longer educational backgrounds (60\% of them are educated for more than 6 years) compare to those who live in the community. No significant difference in the chronic condition both groups have similar multi-morbidity. On the other hand, although depression did not show any significant difference, those who stay in an elderly home likely to be more depressive compare to those who live in the community.

The Activity Daily Living and Instrumental Activity Daily Living are the instrument to measure the dependency level of the elderly based on their ability to perform their daily activities. This finding showed that the elderly living in the nursing home likely to be more dependent than those who living in the community. This finding is in line with the study conducted by Yuliati et al., (2014) who state that elderly living in the community likely to be more independent than those who living in the nursing home. Elderly who live in the community did not lose their support system, and able to do their daily activities independently have good relations with the social environment. In addition, the elderly who have a high level of independence is also able to meet their economic needs.

The significant difference also found on the overall score of quality of life $(p=0.036)$, $56.3 \%$ of the elderly living in the community reported that they have a good quality of life and those who live in the nursing home 57,5\% of them reported poor quality of life. On the other hand, the Visual Analog Scale (VAS), represent the records of the respondent's selfrated health status did not show any significant difference. Using the median cut off point this study identified $55,1 \%$ of the elderly living in the nursing home are reported poor health while the elderly living in the community reported $52,4 \%$ of them to have the good health condition. This finding is in line with former study conducted by (Vitorino, Paskulin, \& Vianna, 2013) who reveal that the concept of health and quality of life are mainly similar between those who stay in Nursing home and community. Being institutionalized did not influence the elderly's perceptions of self-rated health, but the sociodemographic characteristics differ among the two groups.

To figure out the subscale from each dimension, we compare the difference between each construction of the dimension of quality of life.

Based on the figure1, the elderly living in the community have better mobility, self-care ability, better performance in accomplishing their daily activities, and lesser depression symptom compare to those elderly living in the nursing home.

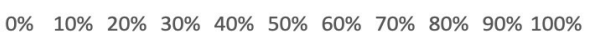

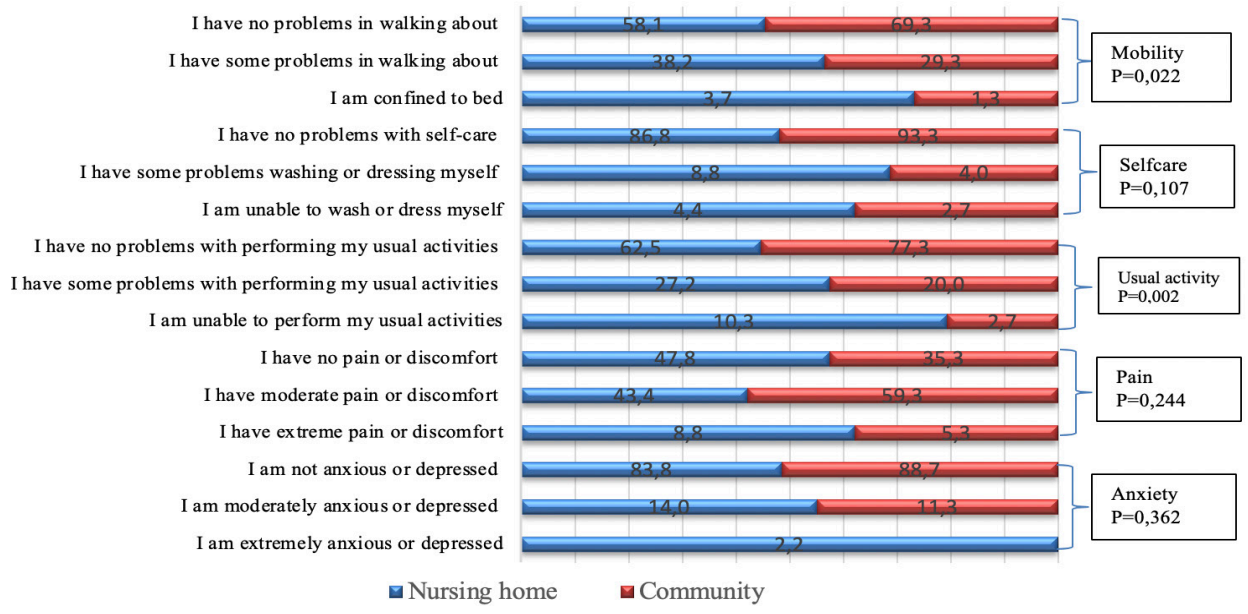

Figure 1. 5 Dimesion of Quality of Life Elderly in Community and Nursing Home 
This study identified the difference in the quality of life among the elderly living in the nursing home and community. The significant difference is found in the dimension of mobility and usual activities. Where $69.3 \%$ of the elderly living in the community reported that they have no problem walking and mobility, while those who stay in the nursing home likely to report that they have a problem walking, and some of them are convinced to bed. This finding is in line with the study conducted by Putri, et.al, (2015) who reveal that the elderly living in community have better physical domain such as physical activity and mobility compared to those who live in the nursing home. The elderly who live in nursing homes tend to face the same environment and limited space. So that their physical activity will be far different from the elderly who live in the community who have good access to their sources of social support such as friends and family.

The usual activity of the elderly living in the nursing home and the elderly living in the community also shows a significant difference statistically. Several studies showed that the ability in performing daily routine is the predictor of quality of life (Borowiak \& Kostka, 2004; Palumbo, Palmerini, Bandinelli, \& Chiari, 2015; Wongsawat, 2017). Living their life each day happily and being able to do daily routine activities, could promote a good quality of life to some extent. Most of the elderly living in the community said that they didn't have any problem in performing the usual activity compare to those who live in the nursing home. This finding can be assumed that elderly people in the community have been living in their homes for decades so they can carry out their usual activities without obstacles. While the elderly who live in homes tend to say that they have limitations in carrying out daily activities because they are in a new environment and many limitations and have to share space with other elderly. The living environment has been well-recognized as the predictor of quality of life (Hajek \& König, 2017; Talarska et al., 2018; Wongsawat, 2017) especially in the dimension of usual activity.

The dimensions of Self-care, pain, and anxiety are likely to be equally experienced by the elderly in nursing homes and communities so that they do not show significant differences. The socio-demographic background of the elderly living in the community and elderly home might become the underlying factor and maybe the cause of differences in quality of life especially in terms of the dimensions of mobility and daily activities. Elderly people living in communities likely more active, walking a lot and have better self-care ability compare to elderly people living in nursing homes. This finding is in line with the study conducted by Yuliastuti \& Anggoro, (2017) who found that elderly living in the nursing home are likely less active compare to those living in the community.

Although the nursing home provide a regular schedule for their residences and the institution requires the elderly to participate in all activities of the institution, not all of the elderly willingly participate in the program. They may burn out with the daily routine. Many elderly skip these activities and prefer convinced in bed. On the other hand, elderly living in community, most of them did not have a routine schedule as they are retired from their job. Some of the elderly may participate in some community activities as they routine daily activities. Family support is crucial for the elderly living in the community to provide a good social environment (Sincihu, Maramis, \& Rezki, 2018). Family routine activities such as social participation which includes maintaining and fostering social relations actively can prevent deterioration in functions such as cognitive function in the elderly which certainly affects the quality of life of the elderly (Ministry of Health Republic Indonesia, 2016).

The usual activities of the elderly are instrumental in increasing social interaction and improving the quality of life of the elderly. For the elderly who live in the elderly home have a lower quality of life in the dimension of usual activity. Living in the nursing home may lead the elderly losing their usual activity as their previous life. This finding is in line with studies conducted by (Gamya, Prasetya, Utami, \& Agrina, 2014; Putra, Agrina, \& Utami, 2014) who observed that the daily activities of the elderly in the community were lower compared to elderly living in the nursing home. The data from the Ministry of Health on Indonesian 
elderly activities also mentioned that the elderly are tend to do sedentary life due to their physical weakness caused by the ageing process (Ministry of Health Republic Indonesia, 2016).

Unlike the elderly who live in nursing homes where all the necessities of their daily lives are met by institutions, the elderly who are in the community tend to have to fulfill their daily needs independently, especially if they do not have a family to accompany them. The elderly who live in the community mostly live alone or together with children who have to work while looking after the elderly. Sometimes the elderly must pass their days alone in a weak physical condition to meet their daily needs. Although the family role not being assessed in this study, we agreed that family role is important in improving the elderly's quality of life (Sincihu et al., 2018). Social interactions that encourage the elderly to actively move are also diminishing and will affect the quality of life of the elderly (Sováriová Soósová, 2016).

\section{Conclusions}

This finding can be concluded that the quality of life of the elderly living in the nursing home community is different in the dimension of mobility and daily activities. This finding implicates a different approach in providing different services in meeting the mobility needs and daily activities of the elderly who live in communities and nursing homes. This study made possible by the support from the ministry of higher education research and technology in the fiscal year $2018-2019$.

\section{References}

Alexandre, T. da S., Cordeiro, R.C., \& Ramos, L.R., 2009. Factors Associated to Quality of Life in Active Elderly. Revista de Saúde Pública, 43(4), pp.613-621.

Borowiak, E., \& Kostka, T., 2004. Predictors of Quality of Life in Older People Living at Home and in Institutions. Aging Clinical and Experimental Research, 16(3), pp.212-220.

BPS., 2017. Statistik Indonesia 2017 (Statistical Yearbook of Indonesia 2017). Jakarta.

Curl, A., Thompson, C.W., Alves, S., \& Aspinall, P., 2016. Outdoor Environmental Supportiveness and Older People's Quality of Life: A Personal Projects Approach. Journal of Housing For the Elderly, 30(1), pp.1-17.

Gamya, T., Prasetya, I., Utami, P., \& Agrina, A., 2014. Perbandingan Kualitas Hidup Lansia Di
Panti Sosial Tresna Werdha Dengan Lansia Di Keluarga. Jurnal Online Mahasiswa (JOM) Bidang Ilmu Keperawatan, 1(2), pp.1-8.

Hajek, A., \& König, H.H., 2017. The Association of Falls with Loneliness and Social Exclusion: Evidence from the DEAS German Ageing Survey. BMC Geriatrics, 17.

Ministry of Health Republic Indonesia., 2016. Situasi Lanjut Usia 2016, 1.

Palumbo, P., Palmerini, L., Bandinelli, S., \& Chiari, L., 2015. Fall Risk Assessment Tools for Elderly Living in the Community: Can We Do Better? PLoS One, 10(12), pp.1-13.

Putra, I. P., Agrina, A., \& Utami, G. T., 2014. Perbandingan Kualitas Hidup Lansia di Panti Sosial Tresna Werdha dengan Lansia di Keluarga. Jom Psik, 1(2), pp.1-8.

Putri, S. T., Fitriana, L. A., Ningrum, A., \& Sulastri, A., 2015. Studi Komparatif Kualitas HidupLansia Yang Tinggal Bersama Keluarga dan Panti (Comparative Study on Quality of Life of The Elderly Living with Their Family and Elderly Home). Jurnal Pendidikan Eperawatan Indonesia, 1(1), pp.9-56.

Reenan, M.V., \& Oppe, M., 2015. EQ-5D-3L User Guide Basic Information on how to use EQ5D-3L. (M. Van Reenan \& M. Oppe, Eds.). Netherland: EuroQol Research Foundation Marten, 5(1).

Riskesdes., 2018. Riskesdas 2018 (National Basic Health Reserach 2018). Kementrian Kesehatan Republik Indonesia (Ministry of Helath Republic Indonesia). Jakarta.

Sincihu, Y., Maramis, W., \& Rezki, N., 2018. Improving Elderly's Quality of Life Through Family Role. Jurnal Kesehatan Masyarakat, 13(3), pp.374-381.

Sováriová, S. M., 2016. Determinants of Quality of Life in Elderly. Central European Journal of Nursing and Midwifery, 7(3), pp.484-493.

Talarska, D., Tobis, S., Kotkowiak, M., Strugała, M., Stanisławska, J., \& Wieczorowska-Tobis, K., 2018. Determinants of Quality of Life and the Need for Support for the Elderly with Good Physical and Mental Functioning. Medical Science Monitor, 24, pp.1604-1613.

UNDESA (United Nation for Departement of Economic and Social Affair)., 2019. World Population Prospect 2019. New York, USA.

Vitorino, L.M., Paskulin, L.M.G., \& Vianna, L.A.C., 2013. Quality of Life of Seniors Living in the Community and in Long Term Care Facilities: A Comparative Study. Revista Latino-Americana de Enfermagem, 21, pp.311.

WHO., 2012. Programme on Mental Health - 
WHOQOL User Manual (Revsion 20). Yuliati, A., Baroya, N., \& Ririanty, M., 2014. Geneva: WHO Press.

Perbedaan Kualitas Hidup Lansia yang Tinggal di Komunitas dengan di Pelayanan Sosial Lanjut Usia (The Different of Quality of Life Among the Elderly who Living at Community and Social Services). Pustaka Kesehatan, 2(1), pp.87-94.

Wongsawat, S., 2017. Predicting Factors for Quality of Life of Elderly in the Rural Area. International Journal of Art \& Sciences, 9(4), pp.363-371.

Yuliastuti, C., \& Anggoro, S.D., 2017. The Overview of The Elderly Lifestyle Profile in Surabaya. Jurnal Kesehatan Masyarakat, 12(2), pp.304313.

Zubritsky, C., Abbott, K.M., Hirschman, K.B., Bowles, K.H., Foust, J.B., \& Naylor, M.D., 2013. Health-related Quality of Life: Expanding a Conceptual Framework to Include Older Adults who Receive Longterm Services and Supports. Gerontologist, 53(2), pp.205-210. 